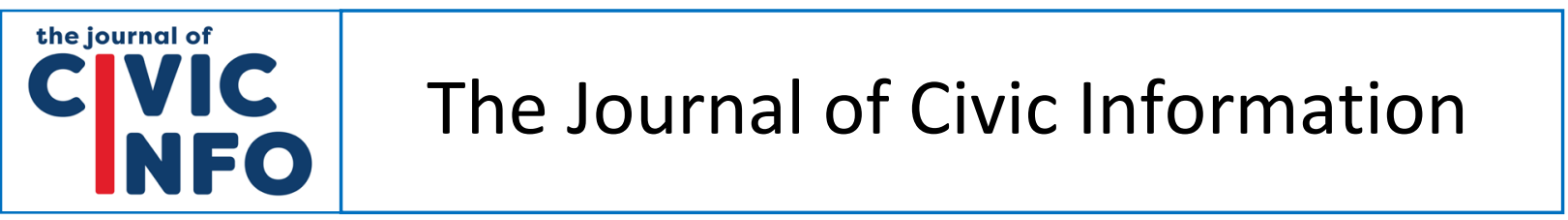

Volume 2 | Number 2

October 2020

\title{
Out from the Curtains of Secrecy: Private University Police and State Open Records Laws
}

\author{
Josh Moore *
}

Article Information

Received: June 30, 2020

Accepted: June 22, 2020

Published: Oct. 31, 2020

Keywords

Freedom of information

Public records

Government transparency

University records

Police records

\begin{abstract}
The role of police officers on college campuses has grown in the past 40 years from that of "glorified custodians" to full-fledged police officers, often with powers to search, detain, arrest, and even to use deadly force. Yet most state open records laws have not kept up, failing to require disclosure of records about crimes reported to or arrests made by sworn police officers at private universities. This article provides a full national picture by identifying the statutes and analyzing the cases to address whether state open records laws apply to private university police. It then suggests that the "functional equivalency test" provides courts a method to require transparency at these police departments.
\end{abstract}

* Josh Moore is a program attorney at the Reporters Committee for Freedom of the Press. Please send correspondence about this article to Josh Moore at jmoore@rcfp.org. An earlier version of this work was presented at National Freedom of Information Coalition summit FOI Research Competition, April 12, 2019, in Dallas, Texas.

To cite this article in Bluebook style: Josh Moore, Out from the Curtains of Secrecy: Private University Police and State Open Records Laws, 2(2) J. CIVIC INFO 1 (2020).

To cite this article in APA style: Moore, J. (2020). Out from the Curtains of Secrecy: Private University Police and State Open Records Laws. Journal of Civic Information, 2(2), 1-21.

DOI: https://doi.org/10.32473/joci.v2i2.126522

Published under Creative Commons License CC BY-NC, Attribution NonCommercial 4.0 International. 


\section{Table of Contents}

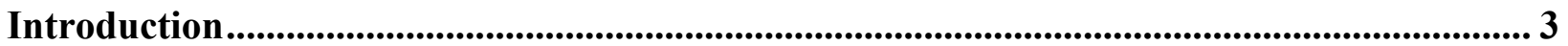

I. The Principles of Openness and Government Authority ................................................. 5

A. The Important Role of Open Records in a Democratic Society ......................................... 5

B. The Functional Equivalency Test's Strong Judicial History with Open Records Laws....... 6

C. How Private University Police Departments Receive Their Arrest Authority.................... 8

II. The Status of the States ........................................................................................................9

A. Court Decisions Subjecting Private University Police to Open Records Laws ................... 9

1. State ex rel. Schiffbauer v. Banaszak (Ohio) .............................................................. 9

2. Salt Lake Tribune v. State Records Committee (Utah) ........................................... 10

3. In re Perrotti v. Chief, Police Department, Yale University (Connecticut) .................... 10

B. Court Decisions Rejected By the State Legislature ...................................................... 11

1. Ochsner v. Elon University (North Carolina) ............................................................ 11

2. Mercer University v. Barrett \& Farahany, LLP (Georgia) ......................................... 12

C. Court Decisions that Failed to Subject Private University Police to Open Records Laws . 12

1. ESPN, Inc. v. University of Notre Dame Security Police Department (Indiana)........... 12

2. Harvard Crimson, Inc. v. President and Fellows of Harvard College (Massachusetts)... 14

III. The Public's Need for Access to Private Universities' Police Records............................ 15

A. Open Records Laws Demand Transparency from All Exercising Governmental Authority 15

B. The Functional Equivalency Test Finds These Records Are Public ................................. 16

1. Private university police departments perform an essential government function .......... 18

2. Private university police officers are subject to continuing government involvement... 20

3. Governments are involved in the creation of private university police departments ...... 20

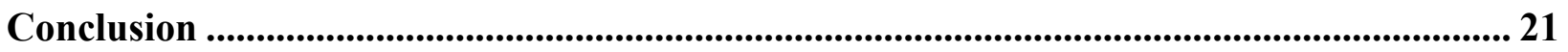




\section{Introduction}

In November 2013, journalists at Houston television station KPRC received a tip about a controversial story: Leaked portions of patrol car footage showed police officers beating a suspected bicycle thief with batons as he lay on a public street. Viewers can hear the suspect, Ivan Joe Waller, screaming while he was struck 13 times within 20 seconds. ${ }^{1}$ It was an important local story about how police approached law enforcement in their community, and it came on the heels of the 2012 fatal shooting of Florida teenager Trayvon Martin and a national conversation about police use of force against people of color. KPRC ran into an unexpected hurdle, though, in obtaining more information about the incident: The police officers who beat and arrested Waller on that public street were employed not by the Houston Police Department, but by Rice University. This distinction was important because Rice, despite being empowered by the Texas legislature to hire police officers with countywide jurisdiction, ${ }^{2}$ asserted that the state's laws requiring some law enforcement transparency did not apply to the private university's police department. ${ }^{3}$

Open records laws, while not perfect, are meant to be one powerful tool for the public to understand the actions of government, to ferret out corruption, or to pinpoint other causes of concern with those in positions of public trust. ${ }^{4}$ There is perhaps no greater position of public trust, of course, than that of a police officer, relied upon to keep the community safe and entrusted with the quintessential governmental authority to detain, search, and arrest. ${ }^{5}$ Police officers at private universities today are often on the same footing as officers employed directly by the government; legislatures or other government bodies grant officers the power to arrest, and even the authority to use deadly force when necessary. ${ }^{6}$ In fact, one piece of the national conversation around police accountability and race in recent years involved an off-campus traffic stop in which a white University of Cincinnati officer fatally shot Samuel DuBose, a Black man who was not connected to the university, after stopping him for a missing front license plate. ${ }^{7}$ Yet, in this era of intense scrutiny of police accountability and of the relationship between law enforcement agencies and their communities, ${ }^{8}$ these private university police departments are often left to patrol themselves.

\footnotetext{
${ }^{1}$ Robert Arnold, Local 2 Investigates Controversial Arrest Involving Rice University Police, KPRC-TV (Nov. 27, 2013), https://perma.cc/N7UM-G5LP.

${ }^{2}$ ABOUT RUPD: OUR AUTHORITY, https://perma.cc/LWC5-QF2D (last visited May 31, 2020).

${ }^{3}$ Robert Arnold, Controversial Police Arrest Prompts Movement to Change Law, KPRC-TV (March 6, 2015), https://perma.cc/7DK8-6NAS (noting that Rice eventually released the full patrol car video after initially refusing to provide it or any additional records about the incident).

${ }^{4}$ See, e.g., TEX. GOV'T CODE $\S 552.001$ ("The people insist on remaining informed so that they may retain control over the instruments they have created.").

${ }^{5}$ See Santiago Legarre, The Historical Background of the Police Power, 9 J. OF CONST. L. 745, 793 (2007).

${ }^{6}$ See State ex. rel. Schiffbauer v. Banaszak, 33 N.E.3d 52, 54 (Ohio 2015) (noting that private university police in Ohio have the authority to confiscate property, search, arrest, and carry deadly weapons).

${ }^{7}$ See The Shooting Of Samuel Dubose, 129 HARV. L. REV. 1168, 1168-69 (2016).

${ }^{8}$ See, e.g., Grace Sparks, Polls Show Widespread Support of Black Lives Matters Protests and Varied Views on How to Reform Police, CNN (June 18, 2020), https://perma.cc/G4J7-85L2 (summarizing multiple public opinion polls conducted in 2020 showing support for various proposals to increase police accountability and transparency following nationwide protests sparked by a white Minneapolis police officer killing George Floyd, a Black man); Samuel Walker, "Not Dead Yet": The National Police Crisis, A New Conversation About Policing, and the Prospects for Accountability-Related Police Reform, 2018 U. ILL. L. REV. 1777, 1784-90 (2018) (describing the national movement for police structural reforms and transparency sparked by multiple incidents of a white police officer killing a black teenager).
} 
In the past 40 years, the role of campus police officers has grown from that of "glorified custodians" 9- their greatest power originating from a heavy set of keys giving them access to all parts of campus - to full-fledged police officers carrying handcuffs, a baton, and often even a pistol. Their role has not just evolved at public institutions; statistics from a 2011-2012 survey of campus police - the most recent data available_-showed that nearly 40 percent of the nation's private colleges and universities employed police officers with full arrest powers, known as "sworn" officers, and most of those carry batons and sidearms. ${ }^{10}$ Reflecting these officers' concentration at universities with larger enrollments, almost half of the students attending private universities in the United States - 45 percent — had sworn and armed police officers on campus. ${ }^{11}$

Since that 2012 survey, states have permitted more private universities to create police departments, and these departments are increasingly large and sophisticated law enforcement agencies. Johns Hopkins University in Baltimore, for example, announced plans to hire about 100 armed officers after it received permission from the Maryland legislature in 2019 to create a police force. ${ }^{12}$ By comparison, only $5 \%$ of all local police departments in the United States employed 100 or more sworn officers in $2013 .{ }^{13}$ Of the nation's 10 largest campus police departments in 2012, seven were at private universities, ranging from 86 to 133 sworn officers. ${ }^{14}$ And these private university police officers often do not just patrol university grounds; a large majority of sworn officers have arrest jurisdiction beyond campus, and many have statewide authority. ${ }^{15}$ The University of Chicago, for example, employs about 100 officers patrolling an area with 65,000 residents, only about 15,000 of whom are students. ${ }^{16}$ Yet the private university refused to release records on the number of stops its officers had made to students and nearby residents investigating whether the department was racially profiling neighborhood residents. ${ }^{17}$

States have only recently begun to take notice of these police officers' unchecked but growing influence on and off campus. Texas, for example, passed legislation in 2015 explicitly applying the state's open records law to private university police departments in response to the incident at Rice. ${ }^{18}$ But while most open records laws have long granted the public access to certain

\footnotetext{
${ }^{9}$ See Jamie P. Hopkins \& Kristina Neff, Jurisdictional Confusion That Rivals Erie: The Jurisdictional Limits of Campus Police, 75 Mont. L. Rev. 123, 126-27 (2014) (describing the initial role of these police officers as "watchmen" with mostly "maintenance-related tasks" (citations omitted)).

10 Brian A. Reaves, Bureau of Justice Statistics, Campus LaW Enforcement, 2011-12, 1, 9 (Jan. 2015), https://www.bjs.gov/content/pub/pdf/cle1112.pdf. This article addresses only these "sworn" officers at colleges and universities possessing arrest powers, and will refer to them generally as "private university police officers."

${ }^{11} I d$.

${ }^{12}$ Pamela Wood, Maryland General Assembly Gives Final OK to Armed Johns Hopkins University Police Force, BALTIMORE SUN (Apr. 2, 2019), https://perma.cc/Q83J-6ZH9. However, after nationwide public outcry over police violence led to protests throughout the spring and summer of 2020, the university hit "pause" on its plans and decided to wait two years. See Lilah Burke, Johns Hopkins Says No Private Police, for Now, INSIDE HigHER ED (June 15, 2020), https://www.insidehighered.com/news/2020/06/15/johns-hopkins-presses-pause-private-police-force-plans.

${ }^{13}$ Brian A. Reaves, Bureau of Justice Statistics, Local Police Departments, 2013: Personnel, Policies, AND PRACTICES 3 (May 2015), https://www.bjs.gov/content/pub/pdf/lpd13ppp.pdf.

${ }^{14}$ Jonah Newman, Police Departments at Illinois Private Universities Get Pass on Releasing Data, CHI. RePORTER (July 7, 2015), https://perma.cc/A6LJ-W878.

${ }^{15}$ REAVES, CAMPUS LAW ENFORCEMENT, supra note 10, at 4 (finding 20 percent of sworn private university police have statewide arrest powers).

${ }^{16}$ Hannah K. Gold, Why Does a Campus Police Department Have Jurisdiction Over 65,000 Chicago Residents?, VICE (Nov. 12, 2014), https://perma.cc/E9D8-ALWY.

${ }^{17}$ Id.; see also Imani J. Jackson \& Frank LoMonte, Policing Transparency, A.B.A. Human Rights Magazine (Jan. 6, 2020), https://perma.cc/LZ6B-3B3S.

18 TEX. EDUC. CODE § 51.212; Arnold, supra note 3.
} 
records - such as arrest reports, jail booking logs, or body-camera video-of law enforcement agencies operated by cities and counties, ${ }^{19}$ most states' laws do not yet explicitly require that transparency from sworn officers at private universities. ${ }^{20}$ The result in those states is often that secrecy prevails when these officers make an arrest or respond to a crime, ${ }^{21}$ as it did originally at Rice. However, activity over the past few years signals the tide may be changing, with eight states now securing public access to at least some private university policing information through statute or judicial decision. ${ }^{22}$

Part I of this article examines the importance of open records laws and how courts have used the functional equivalency test to effectuate the legislative intent behind those laws. It also explains how private universities receive their police powers from the government. Part II provides a picture of the emerging issue of transparency at private university police departments by analyzing cases to confront the issue. Part III argues that open records laws should apply to private university police officers, who perform an essential state function and exercise powers bestowed by and regulated by the government. It suggests that the functional equivalency test provides courts a clear method to require transparency at these police departments even when they are not explicitly listed in a particular state's open records law.

\section{Chapter I. The principles of openness and government authority}

\section{A. The important role of open records in a democratic society}

America's state and federal governments have long recognized the importance of transparency on the part of government agencies. In 1966, President Lyndon B. Johnson signed the Freedom of Information Act ("FOIA") into law, declaring "[n]o one should be able to pull curtains of secrecy around decisions which can be revealed without injury to the public interest." 23

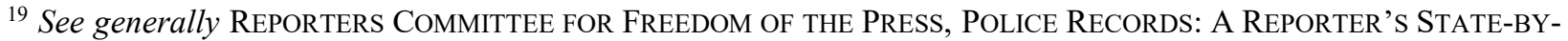
STATE ACCESS GUIDE TO LAW ENFORCEMENT RECORDS 1 (2008), https://www.rcfp.org/wpcontent/uploads/imported/POLICE.pdf ("RCFP GUIDE") (noting that most states require the release of information about arrests and criminal convictions).

20 The federal Jeanne Clery Disclosure of Campus Security Policy and Campus Crime Statistics Act, 20 U.S.C. $\S$ 1092(f) (1990), imposes some requirements on private colleges and universities participating in federal financial aid programs. Id. $\S 1092(\mathrm{f})(1)$. The Clery Act requires them to release: (1) annual campus crime statistics and policies, (2) timely notice to the campus community when a crime is considered to be a threat to others, and (3) a daily crime log. Id. $\S 1092(\mathrm{f})$. However, this does not go as far as open records laws; these crime logs could be as simple as listing the charge, time, and location of the arrest. $I d$. $\S 1092(\mathrm{f})$. Furthermore, this survey does not include statutes that require little or no more than the federal Clery Act. For example, Kentucky's Michael Minger Act mostly mirrors the Clery Act in requiring a daily crime $\log$ and a timely report of crimes deemed a threat to public safety. KY. REV. STAT. 164.948-.9485.

${ }^{21}$ When the Student Press Law Center submitted open records requests to 30 private universities, the only three to provide police records were required to do so by law. Madeline Will, Despite Public Interest in Increased Police Transparency, Most Private Universities Shield Police Reports, Student Press L. CTR. (Mar. 16, 2016), https://perma.cc/M6DA-8XK3.

22 This article only addresses ways to put private universities police departments on the same transparency footing as public departments as relates to open records laws. This is not to suggest that there are not much needed reforms to open records laws to increase transparency of police generally. See, e.g., Marc Levy, Lawmakers Urged to Make Police Discipline Records Public, Assoc. PRESS (June 19, 2020), https://apnews.com/508f480d6950688cefbd62469bac33b6 (describing calls for public access to records regarding police officer misconduct in Pennsylvania and elsewhere).

${ }^{23}$ Presidential Statement on Signing the Freedom of Information Act, 2 PUB. PAPERS 316 (July 4, 1966).
} 
Congress, citing James Madison on the importance of an informed electorate, passed FOIA to create a policy of full disclosure of public information. ${ }^{24}$ The previous federal public information statute had not kept up with the "machinery which makes that society work." 25

Similarly, all 50 state legislatures enacted statutes ensuring the public's right to access information about their governments. ${ }^{26}$ These laws accomplish three tasks: they (1) define what entities and records are subject to disclosure, (2) construct the procedure for requesting and providing the records, and (3) list any exceptions to disclosure. ${ }^{27}$ Legislatures often direct that state open records law be interpreted liberally, ${ }^{28}$ and courts in turn read them to apply as widely as possible. $^{29}$

In particular, public access to police records is an important check on governmental power. The public interest requires full transparency on crime and law enforcement so that citizens can know the risks of living or working in a particular neighborhood or attending a particular school, as well as evaluate the success rates and policies of policing agencies. For example, almost every state's open records law requires the disclosure of some type of "incident report" with various amounts of details about a crime or arrest. ${ }^{30}$ Among many other public uses, those details help journalists, like those covering Waller's arrest by Rice police, report details of the incident and perhaps track down witnesses who can corroborate - or contradict - the police's account. The details also help determine whether universities are reporting accurate crime statistics to prospective and current students. ${ }^{31}$

\section{B. The functional equivalency test's strong judicial history with open records laws}

During the past three decades, courts have increasingly relied on some version of a functional equivalency test to ensure they accomplish the legislative intent behind open records laws. ${ }^{32}$ The test has been a useful tool in determining whether many "private" entities stand in place of public agencies sufficiently to possess the public's information-including a community

\footnotetext{
${ }^{24}$ S. REP. No. 89-813, at 45 (Oct. 4, 1965) (stating that secrecy in government "injures the people it seeks to serve" and "breeds mistrust").

${ }^{25}$ H.R. REP. NO. 89-1497, at 33 (May 9, 1966).

${ }^{26}$ Alexa Capeloto, Transparency on Trial: A Legal Review of Public Information Access in the Face of Privatization, 13 CONN. PUB. INT. L.J. 19, 19 (2013); see, e.g., CAL. GOV'T CODE $§ 6250$ ("“A]ccess to information concerning the conduct of the people's business is a fundamental and necessary right of every person . ..."); IND. CODE § 5-14-3-1 ("Providing persons with the information is an essential function of a representative government ....").

${ }^{27}$ For a detailed look at each state's open records law, see REPORTERS COMMITTEE FOR FREEDOM OF THE PRESS, OPEN GOVERNMENT GUIDE, http://www.rcfp.org/open-government-guide.

${ }^{28}$ See, e.g., NEB. REV. STAT. § 84-712.01(3) (stating the law should be "liberally construed" so citizens "have the full right to know of and have full access to information on the ... public bodies and entities created to serve them"); TEX. GOV'T CODE § 552.001 (stating twice that the Public Information chapter is to be "liberally construed").

${ }^{29}$ See, e.g., Herald Ass'n, v. Dean, 816 A.2d 469, 474 (Vt. 2002) (stating that the Access to Public Records Act must be "liberally construed in favor of public access").

${ }^{30}$ See generally RCFP GUIDE, supra note 19, at 1 (noting that most states require the release of information about arrests and criminal convictions).

${ }^{31}$ For example, journalism students at Tarleton State University used public records to discover that the university failed to disclose several serious incidents - including forcible sex offenses, assaults, and burglaries - in its crime data required by the federal Clery Act. Sydni Dunn, Tarleton State Hit With \$110,000 Fine for Violating Clery Act, STUDENT PRESS L. CTR. (June 8, 2012), https://perma.cc/3VB4-VCCX.

${ }^{32}$ See Ry. Labor Execs.' Ass'n v. Consol. Rail Corp., 580 F. Supp. 777, 778 (D.D.C. 1984) (using a functional analysis because the legislative history of FOIA demonstrated it was intended to include "those entities . . . which perform governmental functions and control information of interest to the public" (citing H.R. REP. No. 93-876 (Mar. 5, 1974))).
} 
fire company (yes), ${ }^{33}$ a corporation managing a public arena (yes), ${ }^{34}$ a humane society (no), ${ }^{35}$ an economic development board (no), ${ }^{36}$ and a public access television nonprofit (yes). ${ }^{37}$ The analysis is also useful, of course, beyond the open records context; courts have long used a functional analysis to determine what entities are subject to other governmental responsibilities, including Fourth Amendment constraints. ${ }^{38}$

Functional equivalency in the open records context traces its roots to a series of federal FOIA cases. ${ }^{39}$ Those courts found statutory definitions were of limited help in determining what was a "public agency" because of the "myriad organizational arrangements for getting the business of the government done," and therefore the courts examined each entity in its own context. ${ }^{40}$ State courts - needing a useful tool in an era of privatization - adopted the analysis in various forms. ${ }^{41}$

At least twenty-four states now employ a version of the functional equivalency test, either as a single question or as a multi-factor test. ${ }^{42}$ Some open records laws explicitly require a functional analysis, ${ }^{43}$ but other courts have adopted the test without direct legislative invitation. ${ }^{44}$ Some states look exclusively to whether the entity performs a public function, ${ }^{45}$ while other states

\footnotetext{
${ }^{33}$ State ex rel. Freedom Commc'ns, Inc. v. Elida Cty. Fire Co., 697 N.E.2d 210, 213 (Ohio 1998) (per curiam) (holding that that a nonprofit company that contracted to provide firefighting services to townships was subject to the state's open records law in part because it was providing a "uniquely governmental" function (citation omitted)).

${ }^{34}$ Allen v. Day, 213 S.W.3d 244, 261 (Tenn. Ct. App. 2006) (finding the private management company to be functionally equivalent to a public agency).

${ }^{35}$ Conn. Humane Soc'y v. Freedom of Info. Comm'n, 591 A.2d 395, 397-99 (Conn. 1991) (deciding the Connecticut Humane Society failed the functional equivalency test because it was not subject to governmental regulation).

${ }^{36}$ Frederick v. City of Falls City, 857 N.W.2d 569, 578-79 (Neb. 2015) (determining the nonprofit was not the functional equivalent of a public office because the function it served - promoting development—could be done by private entities without the involvement of the government).

${ }^{37}$ State ex rel. Toomey v. City of Truth or Consequences, 287 P.3d 364, 370-71 (N.M. Ct. App. 2012) (concluding the nonprofit operating the city's public access cable channel was the equivalent of a public office because it was acting on behalf of the city).

${ }^{38}$ See Evans v. Newton, 382 U.S. 296, 299 (1966) (“'[W] hen private individuals or groups are endowed by the State with powers or functions governmental in nature, they become agencies or instrumentalities of the State and subject to its constitutional limitations.").

${ }^{39}$ See Conn. Humane Soc'y, 591 A.2d at 397 n.3 (noting that the Connecticut Supreme Court used federal case law to develop their test because the state's open records law is about the same subject matter as the federal statute).

${ }^{40}$ Wash. Research Project v. Dep't of Health, Educ. \& Welfare, 504 F.2d 238, 245-46 (D.C. Cir. 1974); see also Irwin Mem'l Blood Bank of S.F. Med. Soc'y v. Am. Nat'l Red Cross, 640 F.2d 1051, 1057-58 (9th Cir. 1981) (holding that the Red Cross was not functionally equivalent because its purpose was to be independent from government); CibaGeigy Corp. v. Mathews, 428 F. Supp. 523, 527-32 (S.D.N.Y. 1977) (finding a federal grant recipient was not functionally equivalent to a government agency).

${ }^{41}$ See generally Craig D. Feiser, Protecting the Public's Right to Know: The Debate over Privatization and Access to Government Information Under State Law, 27 FLA. ST. U.L. REV. 825 (2000) (attempting to classify states' different approaches to privatization).

42 See Capeloto, supra note 26, at 28 (finding, as of 2013, thirteen states use a totality of factors approach and eleven use a public function approach to applying open records laws to private entities, an increase since a similar analysis had been conducted in 1999).

${ }^{43}$ See, e.g., CONN. GEN. STAT. $\S 1-200$ (defining a public agency as any executive, administrative, legislative, or judicial office or any "deemed to be the functional equivalent").

${ }^{44}$ See, e.g., Memphis Publ'g Co. v. Cherokee Children \& Family Servs., Inc., 87 S.W.3d 67, 78 (Tenn. 2002) (rejecting two other approaches - based on legislative determination or agency law-in favor of the functional equivalency test to determine when records were "made or received ... in connection with the transaction of official business by any governmental agency" (citing TENN. CODE § 10-7-301)).

${ }^{45}$ See, e.g., Bryan v. Yellowstone Cty. Elementary Sch. Dist. No. 2, 60 P.3d 381, 387 (Mont. 2002) (finding a committee charged with advising a school district on school closures "performed a legislatively designated governmental function" and thus was a public body).
} 
use a totality-of-the-circumstances approach considering additional factors. ${ }^{46}$ Among those multifactor states, the Connecticut test has been the most influential. ${ }^{47}$ It determines equivalency based on the degree of (1) governmental function, (2) government funding, (3) government involvement or regulation, and (4) government creation. ${ }^{48}$ This article will be framed around that analysis, primarily because the Connecticut test's factors are shaped broadly enough to encompass the additional factors used by other courts, ${ }^{49}$ and it will also cover those states that only weigh the public function factor.

\section{How private university police departments receive their arrest authority}

Police powers are "fundamental power[s] essential to government," 50 retained by the states through the Tenth Amendment of the U.S. Constitution. ${ }^{51}$ They refer to the government's inherent authority 'to establish and enforce laws protecting the public's health, safety, and general welfare, or to delegate this right to local governments." 52 These enforcement powers include the ability to search, detain, and arrest. ${ }^{53}$ Similar to firefighting, taxation, or the exercise of eminent domain, police powers are "uniquely governmental." 54

Thus, private universities do not possess police enforcement powers unless a government entity confers the powers onto them. A handful of states statutorily delegate police enforcement

\footnotetext{
${ }^{46}$ See, e.g., State ex rel. Oriana House, Inc. v. Montgomery, 854 N.E.2d 193, 199 (Ohio 2006).

${ }^{47}$ See, e.g., Cherokee, 87 S.W.3d at 78 (adopting the Connecticut test in Tennessee); Telford v. Thurston Cty. Bd. of Comm'rs, 974 P.2d 886, 894 (Wash. 1999) (adopting the Connecticut test); Jeffrey A. Ware, Clarke v. Tri-Cities Animal Care \& Control Shelter: How Did Private Businesses Become Government "Agencies" Under the Washington Public Records Act?, 33 SeAtTLE U. L. REV. 741, 749-50 (2010) (noting Washington state adopted Connecticut's test (citing 1991 Op. Wash. Att'y Gen. No. 5)).

${ }^{48}$ Bd. of Trs. of Woodstock Acad. v. Freedom of Info. Comm'n, 436 A.2d 266, 270-71 (Conn. 1980); see Andrew C. Helman, Judicial Performance and Policy Implications in Moore v. Abbott, 61 ME. L. REv. 587, 605 (2009) (arguing the broader Connecticut test better achieves legislative intent than the narrower Maine version).

${ }^{49}$ For example, Florida's nine-factor test includes three factors related to public funding. News \& Sun-Sentinel Co. v. Schwab, Twitty \& Hanser Architectural Grp., 596 So. 2d 1029, 1031 (Fla. 1992). All three can fold into "how much government funding the entity receives." See also Telford, 974 P.2d at 894 (determining that two extra factors used by Oregon courts are "not particularly relevant" and can be considered under the other four factors).

${ }^{50}$ POLICE POWER, BLACK'S LAW DICTIONARY (11th ed. 2019).

${ }^{51}$ Hamilton v. Ky. Distilleries \& Warehouse, 251 U.S. 146, 156 (1919).

52 POLICE POWER, BLACK'S LAW DictiONARY (11th ed. 2019); see also 56 AM. JUR. 2D MUNICIPAL CORPORATIONS, ETC. $§ 168$ (2020) ("The governmental functions of a municipal corporation include the promotion of the public peace, health, safety, and morals ....”).

${ }^{53}$ See State v. Walker, 138 P.3d 113, 117 (Wash. 2006) ("The legislature, under its police powers, may grant police officers authority to arrest for certain crimes subject to public policy and constitutional limitations."); Legarre, supra note 5, at 793 (tracking the evolution of the term "police power" from a broad meaning of sovereignty to a narrower meaning of protecting public health, safety, and morals).

${ }^{54}$ Univ. of the Incarnate Word v. Redus, 518 S.W.3d 905, 911 (Tex. 2017) (finding a private university police department to be a "government unit" for purposes of interlocutory appeals under the Texas Tort Claims Act because of the "uniquely governmental" function of law enforcement); Krantz v. City of Hutchinson, 196 P.2d 227, 231 (Kan. 1948) (including "police regulations" and the "suppression of crime" among a list of governmental functions). $C f$. Ayres v. Indian Heights Volunteer Fire Dep't, Inc., 493 N.E.2d 1229, 1235 (Ind. 1986) (finding that — unlike paving streets or building schools or bridges - "firefighting is a service that is uniquely governmental").
} 
powers to private universities, ${ }^{55}$ whether by directly conferring it onto the universities, ${ }^{56}$ or by requiring state police colonels or others to appoint the officers at the request of the university. ${ }^{57}$ In states without an enabling statute, a private university may gain police powers through municipal deputization, whereby the city trains and commissions the officers, who then operate as employees of the university. An agreement between the city and the university governs the officers' patrol area and authority. ${ }^{58}$

\section{Chapter II. The status of the states}

Eight states so far have explicitly required private universities to provide the public access to police records at a similar level as other police departments, while two states have judicial precedent to the contrary. The remaining states appear to have not yet directly faced the question. All 10 states addressing the issue have done so within the past 15 years. Among the eight states ensuring at least some access, six were accomplished by statute: Georgia (2006), North Carolina (2013), Wisconsin (2014), Texas (2015), Virginia (2015), and Utah (2019). ${ }^{59}$ Two of those statutes - Georgia and North Carolina - were seemingly in response to an opposing court decision, while Utah was in response to pending litigation, and the Texas statute was in direct response to the incident at Rice University. Various judicial or administrative decisions added two more proaccess states. The decisions addressing the issue are analyzed below.

\section{A. Court decisions subjecting private university police to open records laws}

\section{State ex rel. Schiffbauer v. Banaszak (Ohio)}

In 2015, the Ohio Supreme Court found a private university's police department to be a "public office" under the state's Public Records Act ${ }^{60}$ and therefore subject to the statute's disclosure requirements. ${ }^{61}$ Otterbein University had argued its police department was not subject to the open records law because it was a subdivision of a private university, which is not a public entity. ${ }^{62}$ In rejecting that argument, the Ohio high court relied upon the plain language of the law, which declares an "entity established by the laws of this state for the exercise of any function of government" to be a public office. ${ }^{63}$ The court held that the department was created under state law because Otterbein could not employ police officers without the Campus Police Departments

\footnotetext{
${ }^{55}$ See Hopkins \& Neff, supra note 9, at 129 (discussing the various types of authorization statutes, including the variation in powers and physical jurisdictional boundaries granted).

${ }^{56}$ See, e.g., 110 ILl. COMP. STAT. 1020/1 (stating that private university police departments should have the same powers as municipal officers and county sheriffs-"including the power to make arrests"- "for the protection of students, employees, visitors and their property").

${ }^{57}$ See, e.g., VA. CODE ANN. § 23.1-812 (authorizing private universities to petition the local circuit court to appoint campus police officers).

${ }^{58}$ Jeffrey S. Jacobson, The Model Campus Police Jurisdiction Act: Toward Broader Jurisdiction for University Police, 29 COLUM. J.L. \& SOC. Probs. 39, 65-67 (1995).

${ }^{59}$ Ga. Code AnN. § 20-8-7; N.C. Gen. Stat. § 74G-5.1; Wis. Stat. AnN. § 19.32; Tex. Educ. Code § 51.212; VA. CODE ANN. § 2.2-3701; UTAH CODE ANN. § 63G-2-103.

${ }^{60}$ OHIO REV. CODE ANN. § 149.43.

${ }^{61}$ State ex. rel. Schiffbauer v. Banaszak, 33 N.E.3d 52, 55 (Ohio 2015).

${ }^{62} \mathrm{Id}$. at 53 .

${ }^{63} \S 149.011$.
} 
Act, ${ }^{64}$ which gave these sworn, state-certified officers the same powers as public officers. ${ }^{65}$ Additionally, Otterbein's department was formed to engage in a function of government, "namely the basic police power of enforcing laws and maintaining the peace." 66 The court did not have to address the plaintiff's alternative argument that the Otterbein police department was the "functional equivalent" of a public office, ${ }^{67}$ but the statute's definition of public office mirrored two factors of the test already. ${ }^{68}$ Otterbein pushed back against the government-creation factor, arguing that, if its enabling statute counted in the analysis, all private corporations created through the state's business laws would be considered public offices because they, too, were created under statute and subject to government regulation. ${ }^{69}$ The court soundly rejected that, however, finding that courts have long considered private corporations to be public offices when they perform a government function. ${ }^{70}$

\section{Salt Lake Tribune v. State Records Committee (Utah)}

A Utah trial court held in 2018 that the police department of Brigham Young University was subject to the state's open records law, and the state legislature enacted a statute codifying that result while an appeal was pending at the Utah Supreme Court. In a detailed decision, the Third Judicial District Court of Salt Lake County found the private university's police department to be a government entity under the Government Records Access and Management Act ("GRAMA"). ${ }^{71}$ Using the analysis called for in the statute's definitions (and again mirroring two of the Connecticut functional equivalency test's four factors), the court found, among other things, the department was "an agency of the state or a political subdivision established by the government [through its enabling statute] to carry out the public's business of policing." 72 Legislation codifying that holding was passed in 2019 while the matter was on interlocutory appeal to the Utah Supreme Court, which subsequently declined to decide the matter on an interlocutory basis because the statute's passage presented the new question of whether it applied retroactively. ${ }^{73}$

\section{In re Perrotti v. Chief, Police Department, Yale University (Connecticut)}

The Connecticut Freedom of Information Commission ("the Commission") made explicit use of the state's functional equivalency test in 2008 in In re Perrotti v. Chief, Police Department,

\footnotetext{
${ }^{64} \S 1713.50$.

65 Schiffbauer, 33 N.E.3d at 54; see also Brief for Ohio Att'y Gen. as Amici Curiae at 1, Schiffbauer (No. 2014-0244) (arguing the department was not "established by" Otterbein, but only through Ohio's delegation of its power).

66 Schiffbauer, 33 N.E.3d at 54.

${ }^{67} \mathrm{Id}$.

${ }^{68}$ Compare $\S 149.011$ (defining a public office as entities "established by the laws of this state" to perform "any function of government”) with Bd. of Trs. of Woodstock Acad. v. Freedom of Info. Comm'n, 436 A.2d 266, 270-71 (Conn. 1980) (listing two factors of the test as whether the entity was created by government and whether it performs a government function).

${ }^{69}$ Schiffbauer, 33 N.E.3d at 54.

${ }^{70}$ Id. (citing Freedom Commc'ns v. Elida Cmty. Fire Co., 697 N.E.2d 210 (Ohio 1998)).

${ }^{71}$ The Salt Lake Tribune v. Utah State Records Comm., No. 160904365, at 23 (Utah Third Judicial Dist. Ct. July 17, 2018).

72 Id. at 23.

${ }^{73}$ Salt Lake Tribune v. State Records Comm., 456 P.3d 728, 731 (Utah 2019).
} 
Yale University ${ }^{74}$ to subject private university police to the state's Freedom of Information Act. ${ }^{75}$ Yale University's police department at least partially met all four factors, but the Commission was particularly persuaded by the government function factor. ${ }^{76}$ The department possessed the power to detain and arrest throughout the City of New Haven, which meant it was capable of having a "profound impact" on individuals. ${ }^{77}$ In looking at the government-funding factor, the Commission noted that the department received "minimal direct government funding" but its tax-exempt status was a "significant" level of indirect funding. ${ }^{78}$ As for government involvement and regulation, the Commission found it was "significant" because the City appointed the officers, who were subject to state training and certification requirements. ${ }^{79}$ City police also provided a number of services to Yale. ${ }^{80}$ Finally, the Commission found that the police department was essentially created by, and dependent on, the government because the Yale officers were originally empowered by the City through a City-University agreement. ${ }^{81}$ Thus, as applied to its law enforcement functions, the Yale police department is subject to the open records law. ${ }^{82}$

\section{B. Court decisions rejected by the state legislature}

\section{Ochsner v. Elon University (North Carolina)}

The North Carolina Court of Appeals held in Ochsner v. Elon University ${ }^{83}$ in 2012 that private university police departments were not subject to the state's Public Records Act, ${ }^{84}$ but the now non-precedential decision may have been based on a legislative oversight. At the time, the open records law defined a "public law enforcement agency" to include a specific list of entities, such as police departments commissioned through the Company Police Act. ${ }^{85}$ It did not, however, include those commissioned through the Campus Police Act, ${ }^{86}$ which was enacted in 2005 and authorized Elon University's and other private universities' police departments. Because those departments were not enumerated in the definition's list, the Court of Appeals held that they were

\footnotetext{
${ }^{74}$ Docket No. DUX 2007-370, 939 (Feb. 2008).

${ }^{75}$ CONN. GEN. STAT. § 1-200(1) (declaring that any person "deemed to be the functional equivalent of a public agency" is considered a public agency).

${ }^{76}$ Perrotti, at 939.

${ }^{77}$ Id. at 91 15. The Commission differentiated Connecticut Humane Society v. Freedom of Information Commission, in which the Humane Society played only a minor role in the state's objective of preventing animal cruelty. 591 A.2d 395, 399 (Conn. 1991).

${ }^{78}$ Perrotti, at 9 ๆ $31,38$.

${ }^{79} \mathrm{Id}$. at $91 \mathrm{~T} 24-25$.

${ }^{80} I d$. at 28 (noting, for example, that City police supervised Yale police on major cases).

${ }^{81} \mathrm{Id}$. at 9 I 18-19. The legislature later formalized the City-University agreement in 1984. Id.

${ }^{82}$ The department is not, however, subject to the open records law for its non-law enforcement functions, such as setting salaries and benefits. Simons v. Freedom of Info. Comm'n, No. CV106007012S, 2011 WL 5304156, at *6 (Conn. Super. Ct. Oct. 17, 2011).

${ }^{83}$ Ochsner v. Elon Univ., 725 S.E.2d 914 (N.C. Ct. App. 2012), affirmed, 737 S.E.2d 737 (N.C. 2013) (per curiam).

${ }^{84}$ N.C. GEN. STAT. § 132.

${ }^{85}$ Ochsner, 725 S.E.2d at 919 . The open records law also includes in its "public law enforcement" definition a city or county police department, a sheriff's department, and a state or local unit that deals with violations of the law. Id. The Company Police Act allows the state's attorney general to certify police agencies of hospitals, state institutions, and corporations. § 74E-2.

${ }^{86} \S 74 \mathrm{G}-2$ (giving the state attorney general the authority to certify private universities' police departments and commission campus police officers).
} 
not subject to the open records law. ${ }^{87}$ The court acknowledged in a footnote, however, that prior to 2005, university police departments were authorized under the Company Police Act instead and would have been subject to the open records law. ${ }^{88}$

Ochsner's effect, however, was limited on appeal and quickly nullified by statute. The North Carolina Supreme Court split 3-3 on review, which left the Court of Appeals ruling standing but without precedential value. ${ }^{89}$ In 2013, as the case was pending before the state supreme court, the North Carolina legislature added a lengthy provision to the state's Campus Police Act that makes the disclosure of some records a condition for certification. ${ }^{90}$

\section{Mercer University v. Barrett \& Farahany, LLP (Georgia)}

The Georgia Court of Appeals determined in 2005's Mercer University v. Barrett \& Farahany, $L L P^{91}$ that private university police departments were not subject to the state's open records law because "there is nothing in the plain and unambiguous language of the Open Records Act that supports such an outcome."92 The plaintiff's argument-which the trial court endorsed $^{93}$ — was a functional equivalency one: Mercer University's police department was a public agency because it was created through and delegated a public function by the legislature in the Campus Policemen Act. ${ }^{94}$ While the Court of Appeals found this to be "a compelling argument," it determined that the precise language of the Georgia open records law required that private entities carrying out a public purpose must do so at the express request of a public office or agency to be subject to the law's transparency requirements. ${ }^{95}$

Just a year after the court's decision, however, the Georgia legislature added an open records section to its Campus Policeman Act. ${ }^{96}$ The statute was the first to explicitly and meaningfully require private university police departments to make its records available to the public.

\section{Decisions that failed to subject private university police to open record laws}

\section{ESPN, Inc. v. University of Notre Dame Security Police Department (Indiana)}

The Indiana Supreme Court held in 2016 that the state's private university police departments were not subject to the Indiana Access to Public Records Act, ${ }^{97}$ overruling the state's

${ }^{87}$ Ochsner, 725 S.E.2d at $920-21$.

${ }^{88} I d$. at 920 n.2. The open record law's language was in place before 2005. See $§ 132-1.4(\mathrm{~b})$.

${ }^{89}$ Ochsner, 737 S.E.2d at 738.

$90 \S 74 \mathrm{G}-5.1(\mathrm{c})$.

${ }^{91} 610$ S.E.2d 138 (Ga. Ct. App. 2005).

${ }^{92} \mathrm{Id}$. at 140-41. The law defined a public agency as a political subdivision of the state; a city, county, or other authority established according to law; or an entity receiving a specified level of government funding. GA. CODE $\S$ 50-18-70(a).

${ }^{93}$ Barrett \& Farahany, LLP v. Mercer Univ., 2004 WL 5905148 (Ga. Super. Ct. 2004), rev'd, 610 S.E.2d 138 (Ga. Ct. App. 2005).

${ }^{94} \S 20-8-2$. The records at issue in this case, relating to rapes and sexual assaults on campus, would have been subject to disclosure had they been created by a local or state police department. $\S \S 50-18-70,72$.

${ }^{95}$ Mercer Univ., 610 S.E.2d at 141-42 (citing Dep't of Human Res. v. Ne. Ga. Primary Care, 491 S.E.2d 201 (Ga. Ct. App. 1997)). The open records law, however, states that public records may belong to private entities "in the performance of a service or function for or on behalf of an agency." $\S 50-18-70$.

962006 GA. LAWS Act 616 (H.B. 1302), now codified at $\S 20-8-7$.

${ }^{97}$ IND. CODE $§ 5-14-3$. 
Court of Appeals decision that they were. ${ }^{98}$ In determining that the University of Notre Dame's police department was not a "law enforcement agency" — defined as "[a]n agency or a department of any level of government that engages in" an enumerated list of police functions ${ }^{99}$ - the Supreme Court acknowledged the department performed police functions, but it found that the statute's phrase "any level of government" excluded private entities. ${ }^{100}$ The court declined to use a functional equivalency test, like that of Ohio, because based on that language, "[t]here is no evidence that our General Assembly intended a functional equivalency analysis" under the open records law. ${ }^{101}$

The court also found that the Notre Dame police department was not a "public agency." In what sounds like an analysis dependent on function, the Access to Public Records Act defines "public agency" as any "department, division, bureau, committee, agency, office . . exercising any part of the executive ... power of the state," or any "other entity, or any office thereof . . . exercising in a limited geographical area the executive ... power of the state." 102 The court held, however, that the Norte Dame police officers themselves were not exercising the power of the state. Instead, in the court's view, it was the university trustees who were entrusted with state powers and who had ultimate control of the police officers. ${ }^{103}$ Because the officers were not directly controlled by the government, the court said the department was not a "public agency." 104 According to the court, the opposite conclusion would have the "absurd" result that "the entire University" could potentially be subject to disclosure requirements, because the police department was not a separate entity from the university. ${ }^{105}$ The court did not address the fact, however, that the statute itself contemplates that an office within an entity could potentially be subject to disclosure while the entity itself is not. ${ }^{106}$

The Indiana Court of Appeals, however, had explained that finding Notre Dame's police department to be a public agency for its law enforcement functions would not transform the university as a whole into a public agency. ${ }^{107}$ The intermediate court, instead, held that the department was the functional equivalent of a public agency because it was "acting as a government entity by exercising a governmental function." 108 The state delegated private university police officers the same sovereign powers that governmental officers possessed, and they could potentially exercise those powers throughout the entire state. ${ }^{109}$ The Court of Appeals found it irrelevant that the department was controlled and financed by Notre Dame's Board of Trustees. ${ }^{110}$

${ }^{98}$ ESPN, Inc. v. Univ. of Notre Dame Police Dep’t, 62 N.E.3d 1192 (Ind. 2016) (“ESPN IF”); ESPN, Inc. v. Univ. of Notre Dame Sec. Police Dep't, 50 N.E.3d 385 (Ind. Ct. App. 2016) (“ESPN I”), vacated by ESPN II, 62 N.E.3d 1192. ${ }^{99} \S 5-14-3-2(\mathrm{q})(6)$, previously at $(\mathrm{n})(6)$.

${ }^{100}$ ESPN II, 62 N.E.3d at 1197.

${ }^{101} I d$.

$102 \S 5-14-3-2(\mathrm{q})(1),(2)(\mathrm{c})$, previously at $(\mathrm{n})(1),(2)(\mathrm{c})$.

${ }^{103}$ ESPN II, 62 N.E.3d at 1198-99; see § 21-17-5-2 (permitting the governing board of universities to appoint police officers).

${ }^{104} I d$.

${ }^{105} \mathrm{Id}$. at $1199-20$.

$106 \S 5-14-3-2(q)(2)(c)$, previously at (n)(2)(c) (defining a "public agency" to include "any . . other entity, or any office thereof ... exercising in a limited geographical area the executive ... power of the state" (emphasis added)).

${ }^{107}$ ESPN I, 50 N.E.3d at 398 (noting that a private entity is only a public agency while performing a government function, and the university's primary function - providing educational services - is not uniquely governmental) (citing State ex. rel. Schiffbauer v. Banaszak, 33 N.E.3d 52, 55 (Ohio 2015)).

${ }^{108}$ ESPN I, 50 N.E.3d at 395.

${ }^{109} \mathrm{Id}$.

${ }^{110} I d$. at 398 n.8. 
In 2017, the Indiana legislature passed a bill over the governor's veto that ostensibly classified private university police departments as public agencies, thus rejecting the Indiana Supreme Court's ruling. ${ }^{111}$ However, transparency advocates have said that the law-backed by the private universities themselves - failed to live up to its promise of transparency because it merely required private universities to disclose what they already were mandated to disclose under the federal Clery Act. ${ }^{112}$ Indeed, the law only requires the departments to release only a small fraction of the records other police agencies are required to release. ${ }^{113}$ Therefore, despite the legislative rejection of the idea that private university police departments are not public agencies, this article does not count Indiana among the states that mandates transparency from them.

\section{Harvard Crimson, Inc. v. President and Fellows of Harvard College (Massachusetts)}

In an opinion that harkens back to a mid-20th century view of campus police, the Massachusetts Supreme Judicial Court held in 2006 that private universities' police records were not subject to the state's open records law. ${ }^{114}$ The party seeking access had argued that Harvard University's police records were public because the state police colonel appointed many of the university's officers as special state police officers under a statute providing them the same arrest powers as other state police officers. ${ }^{115}$ The court disagreed, basing its decision on the fact that the powers were granted, not to the police department as a whole, but to the special officers themselves, whom the state never employed. ${ }^{116}$ The court also pointed out that the special officers' jurisdiction was more limited to a specific geographic area-that of the university's land and structures - than that of regular officers. ${ }^{117}$ The court framed the issue, however, as one relating to "privately employed security guards" with powers "far less extensive than the powers of regular police officers." 118 Today, however, the Harvard police department's brochure and website indicate that its approximately 85 sworn officers "are armed, have arrest powers" and can respond to any "breach of the peace" on the city streets of Cambridge, Somerville, and Boston. ${ }^{119}$

\footnotetext{
${ }^{111}$ IND. CODE $\S 5-14-3-2$.

112 James Hoyt, Experts Say Indiana's Private University Police Transparency Law Has No Teeth, STUDENT PRESS L. CTR. (March 3, 2017), https://perma.cc/7B83-KLBB.

113 § 5-14-3-2.2; see Margaret Fosmoe, Indiana Lawmakers Override Pence Veto on Campus Police Measure, SouTH BEND TRIBUNE (Feb. 15, 2017), https://bit.ly/2YIWzDD.

${ }^{114}$ Harvard Crimson, Inc. v. President and Fellows of Harvard Coll., 840 N.E.2d 518, 523 (Mass. 2006); see MASS. GEN. LAWS ch. 4, $§ 7$.

${ }^{115}$ MASS. GEN. LAws ch. 22C, § 63; Harvard Crimson, 840 N.E.2d at 523.

${ }^{116} \mathrm{Id}$. at 523-24. The state police colonel's regulations require university police departments to submit monthly reports of search and arrest warrants issued to the department and of any felonies on campus. Id. at 525. In the colonel's possession, those reports would be public records. Id.

${ }^{117} \mathrm{Id}$. at 524.

${ }^{118} \mathrm{Id}$. at $523-24$.

119 About, Harvard UnIV. Police DeP'T, https://perma.cc/2RW7-4RDU; Harvard UnIV. POLICE DEP'T, HUPD OVERVIEW PAMPHLET, https://perma.cc/Z8YJ-YLPZ ("The only real difference between a Harvard officer and a Cambridge officer is jurisdiction.").
} 


\section{Chapter III. The public's need for access to private universities' police records}

Sworn private university police officers are performing many of the same important functions as their local and state counterparts, ${ }^{120}$ so it follows that these departments should be subject to the same responsibilities of transparency. While there are other methods to get to this result, ${ }^{121}$ the functional equivalency test has a robust judicial history of safeguarding the legislative intent of transparency in the public's affairs amidst a changing world.

\section{A. Open records laws demand transparency from all exercising governmental authority}

Government is "the people's business,"122 and state legislatures recognized that providing access to that business is fundamental to preventing abuses of the power bestowed by the people. ${ }^{123}$ The legislatures therefore created open records laws with the same objective as FOIA: to create transparency among those entities that "perform governmental functions and control information of interest to the public." 124

The powers that private university police departments possess are rife with the potential for the very kind of abuse these laws are intended to guard against. ${ }^{125}$ In just the two examples discussed previously, Rice University officers were accused of using too much force against a suspect of a nonviolent crime, ${ }^{126}$ and University of Chicago officers were accused of systemically targeting and arresting members of a certain race or social class. ${ }^{127}$ These accusations - even if the exact facts are in contention-represent how unchecked police power can be abused and how the public can come to mistrust it. ${ }^{128}$ Both situations occurred off campus and primarily to people who were not the universities' students, proving that these are records very much "of interest to the public" generally, not just the student and campus population.

The public cannot - and should not have to-depend on others to supervise these police forces. State and local governments, which grant these private universities their police power, have little authority, resources, or incentive to monitor these departments on any ongoing basis. ${ }^{129}$ At

\footnotetext{
${ }^{120}$ See, e.g., GA. CODE $§ 20-8-2$ (stating that private university police officers have the same authority as the local government's police when patrolling the university's land or structures); 110 ILL. COMP. STAT. 1020/1 (providing these police the same powers as municipal officers, including making arrests and enforcing laws, except serving civil process).

121 This article argues a judicial remedy already exists, but explicit statutes would be a welcome-and more expedient-solution.

${ }^{122}$ CAL. GOV'T CODE $\S 6250$.

${ }^{123}$ See WIS. STAT. $§ 19.31$ (stating that a "representative government is dependent upon an informed electorate").

${ }^{124}$ H.R. Rep. No. 93-876, 93d Cong., 2d Sess. 8 (1974); see also Capeloto, supra note 26 (noting that many state open records laws were modeled after the federal version).

${ }^{125}$ See Glik v. Cunniffe, 655 F.3d 78, 82 (1st Cir. 2011) ("[L]aw enforcement officials . . are granted substantial discretion that may be misused to deprive individuals of their liberties.").

${ }^{126}$ Arnold, supra note 1.

${ }^{127}$ Gold, supra note 16.

128 See Doe v. Marsalis, 202 F.R.D. 233, 238 (N.D. Ill. 2001) (explaining that there are many victims of police misconduct in addition to the immediate victim, including other law enforcement officers and agencies, law enforcement efforts generally, and the community at large).

${ }^{129}$ Malcolm K. Sparrow, Managing the Boundary Between Public and Private Policing, New PERSP. IN POLICING BULL. (Nat'1 Inst. of Justice), Sept. 2014, at $21 \mathrm{n} .1$ (noting that police at many private universities are not directly accountable to any public official).
} 
most, governments may require regular reports on the number of crimes these departments see, ${ }^{130}$ but self-reported statistics are not a sufficient or reliable check on such broad powers. Indeed, greater transparency is necessary to ensure these reported crime statistics are accurate and to hold universities accountable when they are not. ${ }^{131}$ Even the most well-intentioned college administrator has an incentive not to call much attention to officer abuse or high crime rates, because those revelations would likely hurt the university's public image, affecting enrollment and donations - the two major revenue drivers of private universities. ${ }^{132}$ In those situations, the interests of the private university police departments are "diametrically opposed to the public interest." 133 The Rice University and University of Chicago incidents are just two examples in which the universities were not originally willing to provide records unless they were required to by law. Fortunately for the public, the spirit and tradition of open records laws, if not the letter of the laws, require these police records be made available to the public to the same extent they would be from a public police department. ${ }^{134}$

\section{B. The functional equivalency test finds these records are public}

Many courts have recognized that a functional equivalency test helps achieve legislative intent, ${ }^{135}$ while being flexible enough to handle the wide range of factual scenarios presented by open records laws and private university police departments. ${ }^{136}$ States' definitions of "public agencies" or other operative terms vary dramatically, ${ }^{137}$ and the various enabling statutes or

\footnotetext{
${ }^{130}$ See Harvard Crimson, Inc. v. President and Fellows of Harvard Coll., 840 N.E.2d 518, 525 (Mass. 2006) (noting that Massachusetts regulations require university police departments to submit monthly reports of warrants and felonies to the state police colonel).

${ }^{131}$ See Collin Binkley et al., Reports on College Crime are Deceptively Inaccurate, THE ColumBus DisPATCH (Sept. 30, 2014), https://perma.cc/G58W-P7SN (finding that crime statistics at most universities are "so misleading that they give students and parents a false sense of security").

${ }^{132}$ See Sparrow, supra note 129, at 19 (explaining that a university has a strong interest in "painting a rosy picture" by downplaying or hiding crime).

${ }^{133}$ Id.; see also Shirley L. Mays, Privatization of Municipal Services: A Contagion in the Body Politic, 34 DuQ. L. REV. 41, 69 (1995) ("Consigning the provision of municipal functions to private organizations is akin to asking the wolf to guard the henhouse.").

${ }^{134}$ Critics might be concerned that the federal Family Educational Rights and Privacy Act ("FERPA") prevents the disclosure of these types of records. However, FERPA explicitly excludes law enforcement records from its protection. 20 U.S.C. § 1232g(a)(4)(B)(ii); see also 34 C.F.R. § 99.8(d) (stating that FERPA does not require nor prohibit the release of law enforcement records). For the purposes of FERPA, law enforcement units are defined as any office or other component of an educational institution designated to enforce local, state, or federal law or to maintain the

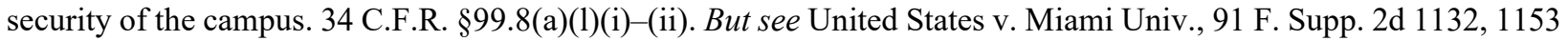
n.22 (S.D. Ohio 1995) (citing Rules and Regulations, Dep’t of Educ., 60 Fed. Reg. 3464-66) (distinguishing law enforcement records from disciplinary records).

${ }^{135}$ See supra Part I-B (finding that versions of the functional equivalency test have been adopted by federal courts, plus courts in Connecticut, Maine, Washington, Oregon, and other states).

${ }^{136}$ See Frederick v. City of Falls City, 857 N.W.2d 569, 576 (Neb. 2015) (concluding "that the four-part functional equivalency approach is the appropriate analytical model" to determining if a private entity is subject to the state's public records laws). Of course, courts do not need to rely on the test if the open records law's language clearly includes private entities that act with state authority. In State ex. rel. Schiffbauer v. Banaszak, the court used the language of the statute, though it used many of the same arguments related to public function and government regulation. 33 N.E.3d 52, 55 (Ohio 2015).

137 Compare CONN. GEN. STAT. $§ 1-200$ (listing a long definition that includes any executive, administrative, legislative, or judicial office of the state or any person "deemed to be the functional equivalent of a public agency") with CAL. GOV’T CODE $§ 6252$ (defining "public agency" as simply “any state or local agency").
} 
municipal deputization agreements create numerous types of police department structures even within the same state. The single question or totality-of-factors tests provide courts a standard but flexible method to keep up with the ever-changing "machinery which makes [this] society work" 138 by supplementing the static, less-than-helpful statutory definitions. ${ }^{139}$ Indeed, that is precisely what the legislatures instructed the courts to do: interpret open records laws liberally to ensure transparency in the public's affairs. ${ }^{140}$ Reading "public office" to include an entity acting as a "public office" achieves that legislative directive for a broad interpretation. ${ }^{141}$

Functional equivalence permits courts to successfully balance the policy of transparency with the competing interest of privacy for purely private entities. It is well aimed at identifying those entities so intertwined with the public's business that they necessarily give up some claims to privacy. ${ }^{142}$ Private companies with only a minor relationship with government ${ }^{143}$ or that perform functions belonging to both the private and public sectors ${ }^{144}$ do not pass the test and would not be subject to open records laws. However, those entities that are government bodies posing as a private agency ${ }^{145}$ or that assume profoundly public functions ${ }^{146}$ are correctly found to be functionally equivalent and subject to open records laws. Critics argue that requiring some semiprivate entities to open their records to the public would unduly burden the entity and defeat productivity in governmental services. ${ }^{147}$ That argument, however, ignores the fact that, from the beginning, our multi-branch, multi-layered system of government was shaped around the notion that safeguards against abuses of power outweigh the need for speed and efficiency. ${ }^{148}$ State legislatures deliberately chose to enact broadly applicable open records laws-including the

\footnotetext{
${ }^{138}$ H.R. REP. NO. 89-1497, at 33 (May 9, 1966) (describing the goal of FOIA).

139 The Harvard Crimson court limited itself to a very static understanding of the statute in 2006 when it stopped its inquiry at the finding that Harvard is a private entity. Harvard Crimson, Inc. v. President and Fellows of Harvard Coll., 840 N.E.2d 518, 523 (Mass. 2006). However, the line between public and private has blurred dramatically over the past decades. Hopkins \& Neff, supra note 9, at 126-27. The functional equivalency test maintains the tradition and legislative intent that police records are open to the public.

140 See, e.g., TEX. GOV’T CODE $§ 552.001$ (a) (stating that the provision should be "liberally construed" to implement the legislature's policy that the people are entitled to "complete information about the affairs of government").

${ }^{141}$ The Ochsner court based its decision on specific statutory language that more likely reflected legislative oversight than legislative intent. See supra Part II-B-2 (discussing the Ochsner case). The functional equivalency test would have kept police records public — as they traditionally were and as the legislature intended them to be. See News \& Observer Pub. v. Poole, 412 S.E.2d 7, 13 (N.C. 1992) (declaring that "the legislature intended to provide that, as a general rule, the public would have liberal access to public records").

${ }^{142}$ See Moore v. Abbott, 952 A.2d 980, 983 (Me. 2008) (using the test to determine if an entity becomes the equivalent of a public agency because of their "activities related to government").

143 See, e.g., Ciba-Geigy Corp. v. Mathews, 428 F. Supp. 523, 527 (S.D.N.Y. 1977) (determining a federal grant recipient was not the functionally equivalent of a public office without more).

${ }^{144}$ See, e.g., Frederick v. City of Falls City, 857 N.W.2d 569, 579 (Neb. 2015) (finding an economic development board was not the functional equivalent because the function it served-promoting development—could be done by private entities without government involvement).

145 See, e.g., Telford v. Thurston Cty. Bd. of Comm'rs, 974 P.2d 886, 894 (Wash. 1999) (holding county officials' membership groups were public because they served a public purpose, were publicly funded, and were run by government employees in their official capacities).

146 See, e.g., Town of Burlington v. Hosp. Admin. Dist. No. 1, 769 A.2d 857, 863 (Me. 2001) (declaring a hospital administrative district was the functional equivalent of a government agency because, among other reasons, it had the power to tax).

147 See Ware, supra note 47, at 766.

148 See Bond v. United States, 564 U.S. 211, 222 (2011) ("By denying any one government complete jurisdiction over all the concerns of public life, federalism protects the liberty of the individual from arbitrary power.").
} 
administrative burden involved-because they knew transparency thwarts corruption and thus leads to more effective representative government. ${ }^{149}$

In the context of private university police departments, the analysis of the factors unquestionably determines these departments are the functional equivalent of public agencies. Three of the four factors are highly relevant and are discussed below. The remaining factorgovernment funding - depends heavily on the facts of each case. Even assuming arguendo that the funding factor does not aid the argument, ${ }^{150}$ private university police departments will still be the functional equivalent of a public office under this totality-of-factors test. Because courts evaluate each situation on a case-by-case basis, ${ }^{151}$ the absence of one or two factors is not dispositive. Instead, coupled with the argument of government creation, the weight of the public function and government regulation factors - if not the public function factor alone-should be dispositive in these cases. $^{152}$

\section{Private university police departments perform an essential governmental function}

Enforcing laws and maintaining the peace are not just minor government functions, but some of the most fundamental government functions. ${ }^{153}$ Indeed, it is "essential to government." 154 Private university police officers have the ability to detain and arrest those they suspect of violating the law, and they are often authorized to use deadly force when necessary. ${ }^{155}$ Those are not mere advisory tasks, ${ }^{156}$ but roles that affect the lives of thousands within the confines of campus, ${ }^{157}$ and often throughout the city, county, or state. ${ }^{158}$

While courts already place great weight on the government function factor, ${ }^{159}$ the presence of the police function should alone be enough, as the Indiana Court of Appeals found in ESPN, to

\footnotetext{
${ }^{149}$ See W. VA. CODE $\S 29$ B-1-1 ("The people insist on remaining informed so that they may retain control over the instruments of government they have created.").

${ }^{150}$ Admittedly, the government does not often provide direct funding to these police departments. But see Perrotti v. Chief, Police Dep't, Yale Univ., Docket No. DUX 2007-370, 938 (finding the Yale police department's tax-exempt status to be a "significant" level of government funding).

${ }^{151}$ Telford v. Thurston Cty. Bd. of Comm'rs, 974 P.2d 886, 894 (Wash. 1999).

${ }^{152}$ See Brief for Ohio Att'y Gen. as Amici Curiae at 1, State ex. rel. Schiffbauer v. Banaszak, 33 N.E.3d 52 (Ohio 2015) (No. 2014-0244) (arguing that police power is such a fundamental public function that it alone creates functional equivalence).

${ }^{153}$ Schiffbauer, 33 N.E.3d at 55; see also United States v. Morrison, 529 U.S. 598, 618 (2000) ("Indeed, we can think of no better example of the police power [entrusted to the states] than the suppression of violent crime and vindication of its victims."). But cf. Ry. Labor Execs.' Ass'n v. Consol. Rail Corp., 580 F. Supp. 777, 778 (D.D.C. 1984) (holding that providing rail service is traditionally a private function).

${ }^{154}$ POLICE POWER, BLACK's LAW DICTIONARY (11th ed. 2019).

${ }_{155}^{155}$ Perrotti, at 9 甲 9, 13.

${ }^{156}$ See Moore v. Abbott, 952 A.2d 980, 983 (Me. 2008) (determining an advisory panel was not functionally equivalent of a public agency because it possessed no decision-making authority).

${ }^{157}$ See, e.g., GA. CODE $\S 20-8-2$ (providing college police officers the same authority as local police when that university police officer is "on the campus").

${ }^{158}$ See Reaves, supra note 10, at 4 (reporting that more than 60 percent of sworn officers at private universities have authority off campus, and 20 percent have authority throughout the state).

${ }^{159}$ See Wash. Research Project v. Dep't of Health, Educ. \& Welfare, 504 F.2d 238, 248 (D.C. Cir. 1974) (declaring the most important consideration in the forerunner to the functional equivalency test was "whether [the entity] has any authority in law to make decisions"); Perrotti, at 39 (acknowledging that the Yale police department was a public agency "based on all the factors, especially the YUPD's exercise of full police powers") (emphasis added).
} 
establish functional equivalence even when using a totality of the circumstances. ${ }^{160}$ The private university police departments often respond to a report of crime on campus in place of public police and perform the same investigatory and peacekeeping tasks those public officers would perform. ${ }^{161}$ Recognizing this functional equivalence, federal and state courts have repeatedly held private university police to the same constitutional standards. ${ }^{162}$ The constitutional state-action analysis is framed differently than the functional equivalency test, but both seek to answer the same question: whether the action or function is infused with governmental authority. ${ }^{163}$ Thus, the situations are analogous. ${ }^{164}$ If a police officer's function, powers, and constitutional limitations do not depend on whether she is employed by a government agency or a private university police department, the openness of the records generated by her should not either. ${ }^{165}$ Courts should be extremely cautious to let governments delegate such broad, grave authority without also applying long-valued, existing statutory safeguards on that power. ${ }^{166}$

\section{Private university police officers are subject to continuing government involvement}

These departments are almost always subject to substantial government involvement and regulation. ${ }^{167}$ Enabling statutes and municipal agreements often require private universities' officers to be trained and certified by the same authorities that a city, county, or state police officer

\footnotetext{
${ }^{160}$ See ESPN, Inc. v. Univ. of Notre Dame. Sec. Police Dep’t, 50 N.E.3d 385 (Ind. Ct. App. 2016) (finding a private university police department performing a government function to be a "public agency," irrespective of being created, controlled, and funded by the university), vacated by ESPN, Inc. v. Univ. of Notre Dame Police Dep't, 62 N.E.3d 1192 (Ind. 2016); Attorney General Brief for Ohio Att'y Gen. as Amici Curiae at 8, State ex. rel. Schiffbauer v. Banaszak, 33 N.E.3d 52 (Ohio 2015) (No. 2014-0244) (“Attorney General Brief") (asserting that "plenary police power is so fundamental to public safety, personal liberty, and law enforcement accountability" that the function factor is sufficient by itself to establish functional equivalence).

${ }^{161}$ See Attorney General Brief, supra note 160, at 11 (stating that prior to the Otterbein Police Department, the city police and county sheriff were the primary responders to campus crime). But $c f$. Conn. Humane Soc'y v. Freedom of Info. Comm'n, 591 A.2d 395, 399 (Conn. 1991) (finding the group played only a minor role in the state's objective of preventing animal cruelty and thus was not functionally equivalent).

${ }^{162}$ See, e.g., Henderson v. Fisher, 631 F.2d 1115, 1118 (3d Cir. 1980) (finding University of Pittsburgh police officers to be state actors under 42 U.S.C. $\S 1983$ because their delegated police powers were infused with a governmental character); Finger v. State, 799 N.E.2d 528, 532 (Ind. 2003) (holding Butler University police officers are state actors subject to the Fourth Amendment because their state-delegated police powers are "a traditionally public function"). These cases ignore the irrelevant distinction made by the Mercer court that the private agency must be carrying out the public purpose at the express request of the government. Mercer Univ. v. Barrett \& Farahany, LLP, 610 S.E.2d 138, 142 (Ga. Ct. App. 2005).

${ }^{163}$ See M. Rhead Enion, Note, Constitutional Limits on Private Policing and the State's Allocation of Force, 59 DuKE L.J. 519, 542 (2009) (arguing that the functional analysis produces a more consistent and correct result than when it is framed through state action).

164 See ESPN I, 50 N.E.3d at 397 (citing constitutional cases for support and finding that, while the open records law "is not constitutional in nature, the same premise applies").

${ }^{165}$ In ESPN II, the Indiana Supreme Court said that police officers must be under government control to be subject to the state's open records law, ESPN, Inc. v. Univ. of Notre Dame Police Dep't, 62 N.E.3d 1192, 1199 (Ind. 2016), but that requirement is simply not in the statute. See IND. CODE § 5-14-32(q)(2)(c) (defining a "public agency" to include "any ... entity, or any office thereof ... exercising in a limited geographical area the executive ... power of the state").

${ }^{166}$ See ESPN I, 50 N.E.3d at 397 ("[T]here is a danger that the public will be denied access to important public documents when a private agency is exercising a public function if we construe APRA to categorically exclude such agencies.").

${ }^{167}$ See Attorney General Brief at 10 (arguing that Otterbein's police department was subject to regulation because of the state training and certification requirements).
} 
would. ${ }^{168}$ These state-mandated and state-controlled training and recertification programs unquestionably represent continuing government involvement in and regulation of the affairs of the police department. ${ }^{169}$ The private university police departments receiving their authority through municipal agreements must also maintain their relationship with the corresponding public police department, which has the right to terminate the agreement. ${ }^{170}$ The right to terminate does not mean that the city "controls" the university police department, but it implies that the city is the dominant party in the relationship. Lines between the two departments are further blurred when the local agency provides essential, day-to-day services to the private university police. ${ }^{171}$

\section{Governments are involved in the creation of private university police departments}

Private universities could not operate police departments without the city or state government expressly delegating its authority. In the statutory model, the state and the university must both act before a department is created. ${ }^{172}$ Under a municipal agreement, the city and university are both parties to the creation. Courts have held that both methods result in private university police departments that are government creations. ${ }^{173}$

In sum, these factors make clear that private university police departments are the functional equivalents of public agencies: (1) the departments perform a traditional and essential government function; (2) the government consistently regulates the departments through training and certification programs, and the government agencies sometimes share resources and otherwise maintain even closer relationships with these departments; and (3) the government is an essential party to the departments' creation. Therefore, private university police departments are carrying out "the people's business" 174 and are subject to open records laws.

\footnotetext{
168 See, e.g., IND. CODE $\S 21-17-5-5$ (stating that university police officers can only exercise their authority after meeting the state's training requirements); Perrotti, at 11.

${ }^{169}$ See id. at II 24-25 (finding that the City of New Haven maintained "significant" control of Yale's police department through the training requirements).

${ }^{170}$ Perrotti, at 911.

${ }^{171}$ See id. at 28 (noting that the city police provide major case supervision, file processing, crime scene services, prisoner transportation and detention, and other services to Yale's police).

172 The Indiana Supreme Court seemed to imply in ESPN that delegating state authority to university trustees, rather than police officers, nullified the state's role in the process. See ESPN, Inc. v. Univ. of Notre Dame Police Dep't, 62 N.E.3d 1192, 1198-99 (Ind. 2016) ("All this is accomplished by the legislature's grant of power to the trustees. The Department is not exercising the power of the State; rather, the trustees are exercising power granted to it by the State to appoint police officers to protect and oversee their campus."). But the quintessential power of the state at issue here is not the act of appointing campus overseers. Instead, it is the ability to search, detain, arrest, and use deadly forceactivities that implicate an individual's liberty. The private university police officers could not do these functions without express delegation of that authority from the state, regardless of what form that delegation takes.

173 See State ex. rel. Schiffbauer v. Banaszak, 33 N.E.3d 52, 55 (Ohio 2015) (determining Otterbein's police department was "established by the laws of this state" because the enabling statute allowed for the department's creation); Perrotti, at 19 (holding that the City of New Haven effectively created Yale's police department through its municipal deputization program).

${ }^{174}$ CAL. GOV’T CODE $§ 6250$.
} 


\section{Conclusion}

Law enforcement powers, such as the ability to detain, arrest, and use deadly force if necessary, are some of the most important of government's functions. With such power comes the need for strong accountability, ${ }^{175}$ and there is an ever-increasing demand for accountability from police departments. Providing the public access to police records gives the public - and the press, the public's surrogate - the ability to audit the department's performance and take them to task for wrongdoing. Do the university's crime statistics submitted under the Clery Act add up? ${ }^{176}$ Did the department cover up officer misconduct in the beating of a suspect? ${ }^{177}$ Is the department mistreating racial minorities in the neighborhoods surrounding the university? ${ }^{178}$ Those records could provide the answers to these questions and more, but only if they are open for public inspection.

As more states begin to confront the issue of police records at private universities, the functional equivalency analysis - or at least the underpinning arguments, no matter what name it takes - will provide a proven method to ensure that courts uphold the legislative's liberal intent of transparency in open records laws. The departments perform the essential state function of enforcing laws and arresting violators, often with broad powers and jurisdictions. Their authority comes directly from governments, whether through statute or municipal deputization, and they are subject to continuing regulation through state-organized training and certification programs. No matter what language the state's open records law employs, these factors make the department the functional equivalent of a public office and accountable under open records laws. Opening up these records prevents private universities from subverting state open records laws ${ }^{179}$ and starts the process of bringing campus crime out from behind the "curtains of secrecy." 180

175 See Randy Ludlow, Dispatch Special Report: Private Cops Being Shielded From the Public, THE COLUMBUS DiSPATCH (Jan. 19, 2014), https://perma.cc/6RTD-RSS6 (listing the arguments for why private police, which have a lot of power in Ohio, should face the same transparency requirements as public police).

176 See Binkley, supra note 131 (detailing the pervasive inaccuracies of crime statistics at most colleges across the country).

177 See Arnold, supra note 1 (discussing the case at Rice University).

178 See Gold, supra note 17 (discussing the accusation against the University of Chicago).

${ }^{179}$ See ESPN, Inc. v. Univ. of Notre Dame Sec. Police Dep't, 50 N.E.3d 385, 398 (Ind. Ct. App. 2016) ("It would not be appropriate for the Police Department, having availed itself of its statutory right to exercise these public functions, to then be able to circumvent public records requirements to which all other entities exercising these same functions are required to adhere.”), vacated by ESPN, Inc. v. Univ. of Notre Dame Police Dep't, 62 N.E.3d 1192 (Ind. 2016).

${ }^{180}$ Presidential Statement on Signing the Freedom of Information Act, 2 PUB. PAPERS 316 (July 4, 1966). 